\title{
PREVALENCE OF WORK-RELATED MUSCULOSKELETAL DISORDERS AMONG HAIRDRESSERS
}

\section{HAPPINESS ANULIKA AWETO ${ }^{1}$, BOSEDE ABIDEMI TELLA ${ }^{1}$, and OMOBOLANLE YEWANDE JOHNSON ${ }^{2}$}

\author{
${ }^{1}$ University of Lagos, Idi-Araba, Lagos, Nigeria \\ Department of Physiotherapy, College of Medicine \\ ${ }^{2}$ Lagos University Teaching Hospital, Idi-Araba, Lagos, Nigeria \\ Department of Physiotherapy
}

\begin{abstract}
Objectives: This study has investigated the prevalence of work-related musculoskeletal disorders (WMSDs), the most commonly affected body parts, the risk factors of WMSDs and the coping strategies adopted by hairdressers. Material and Methods: The study design was a cross-sectional descriptive survey design. Two hundred and ninety-nine hairdressers (242 females and 57 males) from salons in Surulere and Mushin Local Government Areas of Lagos State completed a 27-item questionnaire. They were selected using a non-probability consecutive sampling technique. The inferential analysis was conducted using the $\mathrm{Chi}^{2}$ test. The level of significance stood at $\mathrm{p}<0.05$. Results: The 12-month prevalence of musculoskeletal disorders stood at 75.6\%. Two hundred and twenty-one (91.3\%) participants reported gradual onset of musculoskeletal disorders. One hundred and sixteen (47.9\%) participants had the onset of the WMSDs at the age range of 26-35 years. The most commonly affected body parts included the low back (76.3\%), shoulder (62.5\%) and neck (46.3\%). Some of the major job risk factors of the WMSDs that were identified included: working in the same position for long periods and attending to a large number of customers in 1 day. Taking sufficient rest breaks by participants was one of the coping strategies adopted by the participants. The mean number of years of working experience was $7.85 \pm 0.4$ years. One hundred and twenty-four (41.5\%) participants had worked for 1-5 years. The Chi ${ }^{2}$ analysis showed that the prevalence of musculoskeletal disorders were significantly associated with the age of a participant $\left(\mathrm{Chi}^{2}=78.78, \mathrm{p}=0.001\right)$, years of working experience $\left(\mathrm{Chi}^{2}=78.03, \mathrm{p}=0.001\right)$ and hours spent working in a standing position $\left(\mathrm{Chi}^{2}=8.77, \mathrm{p}=0.01\right)$, respectively. Conclusions: The age of hairdressers, their years of working and the long hours they spent working in a standing position may be significant factors that contribute to the high prevalence of the WMSDs among them. The most commonly affected body parts included the low back, shoulders and neck.
\end{abstract}

Key words:

Prevalence, Workplace, Musculoskeletal abnormalities, Occupational health, Hairdressers

\section{INTRODUCTION}

The work-related musculoskeletal disorders (WMSDs) denote health problems of the loco motor apparatus i.e., muscles, nerves, tendons, joints, cartilages, a spinal disc and related tissues, which have been empirically shown or are suspected to have been associated with exposures to risk factors at a workplace [1]. A high prevalence of the WMSDs has been recorded among workers who are exposed to manual labor, work in unusual and restricted postures, repetitive and

Received: April 8, 2014. Accepted: November 4, 2014.

Corresponding author: H.A. Aweto, University of Lagos, Department of Physiotherapy, College of Medicine, PMB 12003, Idi-Araba, Lagos, Nigeria (e-mail: awetohappiness@gmail.com, haweto@unilag.edu.ng). 
static work, vibrations and poor psychological and social conditions [2].

Musculoskeletal disorders have been described as the most notorious and common causes of severe long term pain and physical disability that may affect hundreds of millions of people across the world [3]. They have also been recognized as one of the leading causes of significant human suffering, loss of productivity and economic burdens on society [3]. In Europe, 1/4 of adults are affected by longstanding musculoskeletal problems that limit everyday activities [4].

In Nigeria, hairdressers operate small scale enterprises engaging from 1 to 10 workers. They engage apprentices who are predominantly female adolescents or out of school youths. Work exposure is unregulated and working conditions are below any standard [5], which is the case with several enterprises of this kind. Various health problems can occur as a result of such exposure. Hairdressers are exposed to a variety of hazards in the workplace. These include chemical agents (products for hair), physical agents (noise, temperature) and ergonomic hazards (inappropriate posture during work and long working hours without breaks) [6]. In Brazil, according to the data from the Social Welfare Ministry, the WMSDs accounted for 52.8\% of occupational diseases registered in 2001, 55.3\% in 2002 and $50.1 \%$ in 2003. It has also been reported in Brazil that the most frequently affected body parts amongst hairdressers include the shoulder, the neck and back [6]. Mussi and Gouveia [6] reported that the prevalence of the WMSDs among hairdressers in Brazil was as high as $71 \%$. Although hairdressers typically spend long hours working on various daily tasks such as cutting, blow drying, perming and washing hair, the volume of data and research effort to explore the WMSDs during these daily tasks has been limited [7]. Most of the few studies conducted on the WMSDs among hairdressers have majorly focused on the shoulder, neck, back, elbow/forearm, hand/wrist and fingers, such as the hip/thigh, knee, ankle and feet, without any due considerations to other parts of the body that may suffer musculoskeletal disorders. Hence, this study was designed to investigate the prevalence of the WMSDs among hairdressers, the most commonly affected body parts, the risk factors of the WMSDs and the coping strategies adopted by hairdressers in Surulere and Mushin Local Government Areas of Lagos State, Nigeria.

\section{MATERIAL AND METHODS}

A total of 299 hairdressers (242 females, 57 males) participated in this study. They were recruited from various hairdressing salons in Surulere and Mushin Local Government Areas of Lagos State, Nigeria. They were selected using a non-probability consecutive sampling technique. They were all full-time working hairdressers who had had at least 1 year post-training experience. An ethical approval was obtained from the Health Research and Ethics Committee of the Lagos University Teaching Hospital, Idi-Araba, Lagos. An informed consent was obtained from each of the participants. Their heights and weights were taken after they had completed a 27-item questionnaire.

\section{Questionnaire design}

This questionnaire titled "Evaluation of the prevalence of work-related musculoskeletal disorders among hairdressers" was adopted from the Nordic Musculoskeletal Questionnaire [8]. It had 6 sections.

- Section A - collected information on the demographic data of the participants.

- Section B - collected information on the working experience of the hairdressers.

- Section C - collected information on musculoskeletal disorders.

- Section D - collected information on effects of work-related musculoskeletal disorders on the job performance.

- Section E - collected information on the possible predisposing factors to musculoskeletal disorders. 
- Section F - collected information on the coping strategies the hairdressers adopted to reduce strain on their body.

\section{Administration of questionnaire}

The aims and objectives of the study were clearly stated to all the subjects who were assured of the confidentiality of their responses. The copies of the questionnaire were distributed to them by the researchers and the completed questionnaires were immediately collected.

\section{Data analysis}

Descriptive statistics of frequency, percentage rates and inferential statistics of the $\mathrm{Chi}^{2}$ were used for analyzing data. The results were displayed using tables and bar charts. The level of significance was $p<0.05$.

\section{RESULTS}

A total of 305 copies of questionnaire were distributed and 299 copies were returned accounting for the response rate at $98.0 \%$. The mean age, height, weight and body mass index (BMI) of the participants was $32.5 \pm$ 4.9 years, $1.75 \pm 0.12 \mathrm{~m}, 65.5 \pm 9 \mathrm{~kg}$ and $24.29 \pm 1.9 \mathrm{~kg} / \mathrm{m}^{2}$, respectively. The point prevalence of the WMSDs among participants was $81 \%$ (242 participants), 12-month prevalence was $75.6 \%$ (226 participants) and career prevalence was $74.9 \%$ (224 participants). Two hundred and twenty-one $(91.3 \%)$ participants reported the gradual onset of musculoskeletal disorder. One hundred and thirty-three $(55 \%)$ participants had their 1st experience of the WMSDs in the first 5 years of working (Table 1). One hundred and sixteen (47.9\%) participants had the onset of the WMSDs at the age range of 26-35 years, $87(36 \%)$ - at the age range of 20-25 years, $27(11.3 \%)$ at the age below 20 years old, $9(3.6 \%)$ - at the age range of 36-40 years old, $2(0.8 \%)$ - at the age range of 41-45 years old and $1(0.4 \%)$ participant - at the age range of $46-50$ years.
The 3 most prone body parts to the WMSDs among the participants included the low back (228 (76.3\%) participants), shoulder (180 (60.2\%) participants) and neck (130 (46.3\%) participants). The 3 least prone body parts included the upper back (14 (4.6\%) participants), elbow/forearm (45 (14.9\%) participants) and hip/thigh (50 (16.6\%) participants). Some participants reported multiple body parts of discomfort while others had a single body part of discomfort (Figure 1).

Fifty-three (17.7\%) participants had a break in their career paths. Nineteen $(35.8 \%)$ participants took a break as a result of body pains. Two hundred participants (66.9\%) worked for 4-6 days in a week. One hundred and seventynine $(59.9 \%)$ participants spent $6-10 \mathrm{~h}$ standing to make hair in a day. Two hundred and ninety-three (98\%) participants took breaks during the working hours (Table 2). Only $48(16.1 \%)$ participants claimed that the WMSDs affected their daily activities. Eighty (26.8\%) participants reported that symptoms had a negative effect on the efficiency of their job performance. Two hundred and six $(68.9 \%)$ participants reported that the nature of their job did not aggravate an already existing injury (Table 3 ). The 5 major job risk factors that were identified included: working in the same position for long periods, attending to a large number of customers in 1 day, work scheduling,

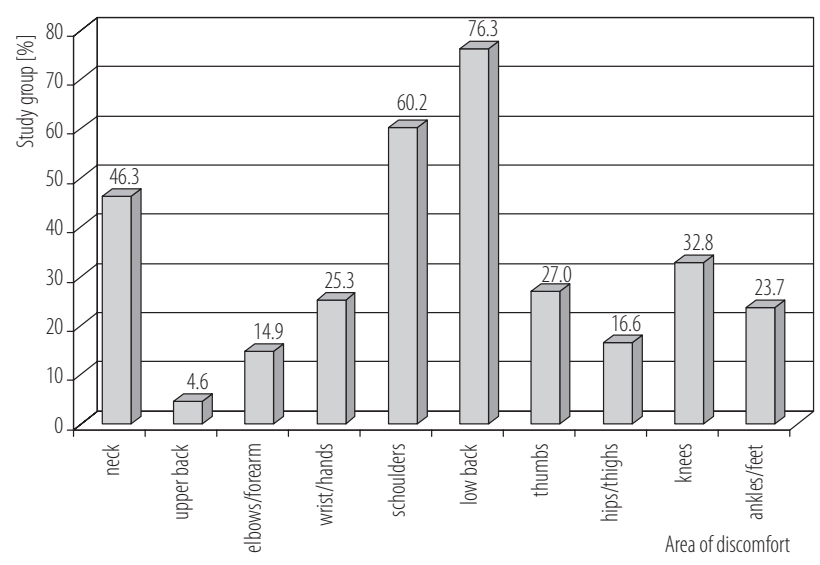

Fig. 1. Major areas of the bodily pain in the study group 
Table 1. Point prevalence, 12-month prevalence and career prevalence of work-related musculoskeletal disorders (WMSDs), onset and 1st experience of discomfort in the study group

\begin{tabular}{|c|c|c|}
\hline \multirow[t]{2}{*}{ Variable } & \multicolumn{2}{|c|}{$\begin{array}{l}\text { Study group } \\
(\mathrm{N}=299)\end{array}$} \\
\hline & $\mathrm{n}$ & $\%$ \\
\hline \multicolumn{3}{|l|}{ Point prevalence } \\
\hline yes & 242 & 80.9 \\
\hline no & 57 & 19.1 \\
\hline total & 299 & 100.0 \\
\hline \multicolumn{3}{|l|}{ 12-month prevalence } \\
\hline yes & 226 & 75.6 \\
\hline no & 20 & 6.7 \\
\hline no response & 53 & 17.7 \\
\hline total & 299 & 100.0 \\
\hline \multicolumn{3}{|l|}{ Career prevalence } \\
\hline yes & 224 & 74.9 \\
\hline no & 16 & 5.4 \\
\hline no response & 59 & 19.7 \\
\hline total & 229 & 100.0 \\
\hline \multicolumn{3}{|l|}{ Onset of discomfort } \\
\hline gradual & 221 & 91.3 \\
\hline sudden & 19 & 7.9 \\
\hline no response & 2 & 0.8 \\
\hline total & 242 & 100.0 \\
\hline \multicolumn{3}{|l|}{ First experience of discomfort } \\
\hline before becoming a hairdresser & 22 & 9.1 \\
\hline in the first 5 years of being a hairdresser & 133 & 55.0 \\
\hline $5-15$ years of being a hairdresser & 85 & 35.1 \\
\hline$>15$ years of being a hairdresser & 1 & 0.4 \\
\hline no response & 1 & 0.4 \\
\hline total & 242 & 100.0 \\
\hline
\end{tabular}

performing the same task over and over and not having sufficient rest breaks during the day (Table 4).

The 3 major coping strategies employed by the participants to prevent musculoskeletal disorders were: sufficient rest breaks, discontinuation of attending to customers if it causes or worsens discomfort and selection of a technique that will not aggravate their discomfort (Table 5).
One hundred and sixty-seven $(69.0 \%)$ participants resorted to self-treatment, $58(24.0 \%)$ participants visited the clinic for treatment, $1(0.4 \%)$ participant was admitted on the account of symptoms and $16(6.6 \%)$ participants were silent on their management of the WMSDs.

The participants within the age range of 26-30 years $(88.5 \%)$ experienced more discomfort. The $\mathrm{Chi}^{2}$ 
Table 2. Work settings in the study group

\begin{tabular}{|c|c|c|}
\hline \multirow[t]{2}{*}{ Variable } & \multicolumn{2}{|c|}{$\begin{array}{c}\text { Study group } \\
(\mathrm{N}=299)\end{array}$} \\
\hline & $\mathrm{n}$ & $\%$ \\
\hline \multicolumn{3}{|c|}{ Participants who have had a break in the career path } \\
\hline yes & 53 & 17.7 \\
\hline no & 241 & 80.6 \\
\hline no response & 5 & 1.7 \\
\hline total & 299 & 100.0 \\
\hline \multicolumn{3}{|l|}{ Reasons for taking a break } \\
\hline body pains & 19 & 35.8 \\
\hline travelled & 3 & 5.7 \\
\hline schooling & 3 & 5.7 \\
\hline rest & 1 & 1.9 \\
\hline others & 3 & 5.7 \\
\hline no response & 24 & 45.2 \\
\hline total & 53 & 100.0 \\
\hline \multicolumn{3}{|c|}{ Participants who take breaks during working hours } \\
\hline yes & 293 & 98.0 \\
\hline no & 6 & 2.0 \\
\hline total & 299 & 100.0 \\
\hline \multicolumn{3}{|l|}{ Working [days/week] } \\
\hline $1-3$ & 8 & 2.7 \\
\hline $4-6$ & 200 & 66.9 \\
\hline 7 & 88 & 29.4 \\
\hline no response & 3 & 1.0 \\
\hline total & 299 & 100.0 \\
\hline \multicolumn{3}{|l|}{ Time spent standing to make hair $[\mathrm{h}]$} \\
\hline $1-5$ & 25 & 8.4 \\
\hline $6-10$ & 179 & 59.9 \\
\hline $11-15$ & 95 & 31.8 \\
\hline total & 299 & 100.0 \\
\hline
\end{tabular}

analysis showed that there was a significant association between the age of participants and the prevalence of musculoskeletal disorders $\left(\mathrm{Chi}^{2}=78.78, \mathrm{p}=0.001\right)$. One hundred and twenty-four (41.5\%) participants had worked for 1-5 years. There was also a significant association between years of working experience and the prevalence of musculoskeletal disorders $\left(\mathrm{Chi}^{2}=78.03, \mathrm{p}=0.001\right)$. Hairdressers who worked for 6-10 $\mathrm{h}$ in a day (76\%) had more discomforts. A significant association was also observed between hours spent working in a standing position and the prevalence of musculoskeletal disorders among hairdressers $\left(\mathrm{Chi}^{2}=8.77, \mathrm{p}=0.01\right)($ Table 6$)$. 
Table 3. Effects of work-related musculoskeletal disorders (WMSDs) on health and job performance in the study group

\begin{tabular}{|c|c|c|}
\hline \multirow[t]{2}{*}{ Variable } & \multicolumn{2}{|c|}{$\begin{array}{l}\text { Study group } \\
(\mathrm{N}=299)\end{array}$} \\
\hline & $\mathrm{n}$ & $\%$ \\
\hline \multicolumn{3}{|l|}{ Symptoms affect daily activities } \\
\hline yes & 48 & 16.1 \\
\hline no & 201 & 67.2 \\
\hline no response & 50 & 16.7 \\
\hline total & 299 & 100.0 \\
\hline \multicolumn{3}{|l|}{ WMSDs affected job efficiency } \\
\hline yes & 80 & 26.8 \\
\hline no & 169 & 56.5 \\
\hline no response & 50 & 16.7 \\
\hline total & 299 & 100.0 \\
\hline \multicolumn{3}{|l|}{ Work aggravated an already existing injury } \\
\hline yes & 43 & 14.4 \\
\hline no & 206 & 68.9 \\
\hline no response & 50 & 16.7 \\
\hline total & 299 & 100.0 \\
\hline
\end{tabular}

Table 4. Risk factors to work-related musculoskeletal disorders (WMSDs) in the study group

\begin{tabular}{|c|c|c|c|c|}
\hline \multirow[t]{2}{*}{ Risk factor } & \multicolumn{4}{|c|}{$\begin{array}{c}\text { Study group } \\
(\mathrm{N}=299) \\
{[\mathrm{n}(\%)]}\end{array}$} \\
\hline & irrelevant & in a minor way & moderately & severely \\
\hline Performing task over and over again & $9(3.9)$ & $58(24.9)$ & $81(34.8)$ & $85(36.5)$ \\
\hline Attending to a large number of customers within 1 day & $2(0.9)$ & $16(6.8)$ & $100(42.6)$ & $117(49.8)$ \\
\hline No sufficient rest breaks during the day & $4(1.7)$ & $61(26.0)$ & $96(40.9)$ & $74(31.5)$ \\
\hline $\begin{array}{l}\text { Working in the same position for long periods } \\
\text { (e.g., standing, bent over) }\end{array}$ & $3(1.3)$ & $18(7.7)$ & $89(38.0)$ & $124(53.0)$ \\
\hline Bending or twisting back in an awkward position & $51(22.1)$ & $116(50.2)$ & $32(13.9)$ & $32(13.9)$ \\
\hline Reaching or working away from the body & $92(40.0)$ & $103(44.8)$ & $24(10.4)$ & $11(4.8)$ \\
\hline Working near to or at your physical limit & $29(12.6)$ & $123(53.2)$ & $56(24.2)$ & $23(10.0)$ \\
\hline Unanticipated sudden movement & $100(43.5)$ & $102(44.3)$ & $15(6.5)$ & $13(5.7)$ \\
\hline Continuing to work when injured or hurt & $14(6.1)$ & $90(39.0)$ & $93(40.3)$ & $34(14.7)$ \\
\hline Work scheduling (e.g., length of day work or overtime etc.) & $1(0.4)$ & $12(5.2)$ & $109(46.8)$ & $111(47.6)$ \\
\hline
\end{tabular}


Table 5. Coping strategies adopted by participants due to work-related musculoskeletal disorders (WMSDs)

\begin{tabular}{|c|c|c|c|}
\hline \multirow[t]{2}{*}{ Coping strategy } & \multicolumn{3}{|c|}{$\begin{array}{c}\text { Study group } \\
(\mathrm{N}=299) \\
{[\mathrm{n}(\%)]}\end{array}$} \\
\hline & ineffective & moderately effective & very effective \\
\hline I get someone to help pick things I need around & $175(75.8)$ & $47(20.3)$ & $9(3.9)$ \\
\hline I modify my position so as to be comfortable & $127(55.0)$ & $71(30.7)$ & $33(14.3)$ \\
\hline I pause regularly so I can stretch and change posture & $168(72.4)$ & $47(20.3)$ & $17(7.3)$ \\
\hline I select a technique that will not aggravate my discomfort & $115(49.8)$ & $92(39.8)$ & $24(10.4)$ \\
\hline I stop attending to customers if it causes or worsens discomfort & $100(42.9)$ & $90(38.6)$ & $43(18.5)$ \\
\hline I take sufficient rest breaks & $26(11.2)$ & $124(53.4)$ & $82(35.3)$ \\
\hline I perform supervising work & $144(61.8)$ & $73(31.3)$ & $16(6.9)$ \\
\hline
\end{tabular}

Table 6. Association between the prevalence of work-related musculoskeletal disorders and other variables

\begin{tabular}{|c|c|c|c|c|c|}
\hline \multirow[t]{2}{*}{ Variable } & \multicolumn{3}{|c|}{$\begin{array}{c}\text { Study group } \\
(\mathrm{N}=299) \\
{[\mathrm{n}(\%)]}\end{array}$} & \multirow[t]{2}{*}{$\mathrm{Chi}^{2}$} & \multirow[t]{2}{*}{$\mathrm{p}$} \\
\hline & yes & no & total & & \\
\hline Age [years] & & & & 78.78 & $0.001^{*}$ \\
\hline $15-20$ & $13(33.3)$ & $26(66.7)$ & $39(13.0)$ & & \\
\hline $21-25$ & $62(77.5)$ & $18(22.5)$ & $80(26.8)$ & & \\
\hline $26-30$ & $77(88.5)$ & $10(11.5)$ & $87(29.1)$ & & \\
\hline $31-35$ & $54(94.7)$ & $3(5.3)$ & $57(19.1)$ & & \\
\hline $36-40$ & $17(100.0)$ & - & $17(5.7)$ & & \\
\hline $41-45$ & $16(100.0)$ & - & $16(5.3)$ & & \\
\hline$>45$ & $3(100.0)$ & - & $3(1.0)$ & & \\
\hline Working [years] & & & & 78.03 & $0.001^{*}$ \\
\hline $1-5$ & $76(61.3)$ & $48(38.7)$ & $124(41.5)$ & & \\
\hline $6-10$ & $92(94.8)$ & $5(5.2)$ & $97(32.4)$ & & \\
\hline $11-15$ & $47(92.2)$ & $4(7.8)$ & $51(17.1)$ & & \\
\hline $16-20$ & $20(100.0)$ & - & $20(6.7)$ & & \\
\hline$>20$ & $7(100.0)$ & - & $7(2.3)$ & & \\
\hline Time spent standing to make hair [h] & & & & 8.77 & $0.010^{*}$ \\
\hline $1-5$ & $19(76.0)$ & $6(24.0)$ & $25(8.4)$ & & \\
\hline $6-10$ & $136(76.0)$ & $43(24.0)$ & $179(59.9)$ & & \\
\hline $11-15$ & 87 (91.6) & $8(8.4)$ & $95(31.8)$ & & \\
\hline
\end{tabular}

* Statistically significant. 


\section{DISCUSSION}

The study was designed to evaluate the prevalence of the WMSDs among hairdressers in Surulere and Mushin Local Government Areas of Lagos State, Nigeria. The prevalence of the WMSDs among the hairdressers was observed to be $81 \%$. The low back pain was the most common area of discomfort, followed by the shoulder and then the neck. Work-related musculoskeletal disorders did not affect $3 / 4$ of the participants' daily activities and $2 / 3$ of the participants reported that symptoms had no effect on their job efficiency. The majority of the participants had a gradual onset of musculoskeletal disorder while $7.9 \%$ reported a sudden onset. The 5 major job risk factors that were identified in the hairdressing task included: working in the same position for long periods, attending to a large number of customers within 1 day, work scheduling, not having sufficient rest breaks during the day and performing the same task over and over.

The prevalence of the WMSDs among the hairdressers that has been observed to stand at $81 \%$ in this study implies that it is very high. The result of the study by Mussi and Gouveia [6] on the prevalence of the WMSDs among hairdressers in Brazil showed a high prevalence of $71 \%$. The Bureau of Labor Statistics [9] also showed a high incidence of the WMSDs, especially the low back pain (LBP) in different occupational groups and this contributed to large economic losses to individuals as well as to the community.

The finding that the most common area of discomfort has been the low back may be due to stress imposed on the lower vertebral structures in a prolonged standing position. Stefanakis et al. [10] reported that mechanical loading could initiate disc degeneration and that stress gradients acted to shear adjacent lamellae and could explain progressive annulus delamination and collapse. The other most common body parts affected by the WMSDs included the shoulder and the neck. Okojie and Isah [11] also reported that back pain was the most common musculoskeletal disorder experienced by hairdressers in Benin City, Nigeria. Guo [12] pointed out that out of the top 15 major occupations, female hairdressers and cosmetologists are ranked the 3rd to be at risk for low back pain attributed to work. However, studies by Wu et al. [13] and Chuang [14] observed that the shoulders were the most common area of discomfort experienced by hairdressers followed by the low back and the neck. Mussi and Gouveia [6] reported that the shoulders were the most commonly affected body part followed by neck and back among the Brazilian hairdressers. English et al. [15] observed that the shoulders were the most commonly affected body part in the case of female hairdressers. Lin [16] observed that out of the many non-self-employed workers who were claiming compensation from labor insurance from 1999 to 2001, hairdressers in Taiwan were making the most claims for upper limb disorders.

Contrary to the finding that the WMSDs did not affect majority of the hairdressers' daily activities and job efficiency, Fang et al. [7], Chuang [14] and Wu et al. [13] reported that musculoskeletal discomfort, injury and harm among hairdressers might result not only in decreased job performance and lower productivity but also in increased off-work time and early retirement from this profession.

The observation that the majority of the hairdressers had a gradual onset of musculoskeletal disorder while just a few reported a sudden onset may be due to gradual degeneration of the affected musculoskeletal tissues resulting from wear and tear.

The high prevalence rates of musculoskeletal discomfort in the low back, shoulder and neck may be associated with occupational factors contributing to undue stress on the various body parts. In this study, 5 major occupational risk factors that were identified in the hairdressing task included: working in the same position for long periods, attending to a large number of customers in 1 day, work scheduling, not having sufficient rest breaks during the day and performing the same task over and over. 
In 2 systematic reviews conducted by Porter and Gyi [17] and Lis et al. [18], it was found that staying in a particular posture for a long time e.g., sitting for more than half a workday, combined with whole body vibration and/ or awkward postures increased the risk of LBP $[17,18]$. It is the combination of these risk factors that leads to the greatest incidence of the LBP. Mussi and Gouveia [6] reported that the risk factors associated with the occurrence of the WRMDs among the Brazilian hairdressers were mostly related to biomechanical (uncomfortable posture at work) and psychosocial factors (lack of acknowledgement of work) and length of professional engagement. Leino et al. [19] stated that risk factors causing significant discomfort and even work-related diseases for the workers in the salons included repetitive movements, awkward working postures, standing, draughts, uncomfortable temperatures and use of chemicals, tools and equipment.

There was a significant relationship between the age and the prevalence of the WMSDs suggesting that the older hairdressers are getting, the higher the prevalence was. This may be due to degenerative changes associated with ageing which were exaggerated by undue stress placed on the various body parts by the identified risk factors. Fang et al. [7] observed that aging effect could be one of the risk factors of musculoskeletal disorders for Taiwanese hairdressers leading to discomfort in the lower back and lower leg. This also corresponds with the finding of Guo et al. [20], who reported that the prevalence of musculoskeletal disorders increased as people enter their working years and by the age of 35 most people had had their 1st episode of back pain.

There was a significant relationship between the years of working experience and the prevalence of the WMSDs among the participants. This corresponds with the finding of Mussi and Gouveia [6], who reported that one of the risk factors associated with the occurrence of the WMSDs among hairdressers, was their length of professional engagement. However, Fang et al. [7] reported that there was no significant effect of years of working experience on discomfort in body parts of Taiwanese hairdressers.

There was also a significant association between the hours spent working in a standing position and the prevalence of musculoskeletal disorders among the participants. This may be due to stress imposed on the body structures as a result of increased load in a prolonged standing position. Leino et al. [19] reported that standing was one of the risk factors that caused significant discomfort and even work-related diseases for the workers in the salons. Takala [21] reported that most musculoskeletal disorders were cumulative disorders resulting from repeated exposure to high or low intensity loads over a long period of time.

\section{CONCLUSIONS}

Age of hairdressers, their years of working and the long hours they spent working in a standing position may be significant factors that contribute to the high prevalence of the WMSDs among them. The most commonly affected body parts included the low back, shoulders and neck. Taking sufficient rest breaks was one of the major coping strategies they adopted.

\section{Recommendations}

Based on the findings of this study, it is hereby recommended that hairdressers should be enlightened - on a regular basis - on the high prevalence of the WMSDs among them, the possible predisposing factors and the precautionary measures to be taken in order to prevent the development. Health education has proven to yield positive results e.g., Crippa et al. [22] reported that there were some changes in hairdressing practice (e.g., use of gloves, barrier creams, skin care products) and procedures and this resulted in a decrease in work-related dermatitis after specific educational programmes had been offered to hairdressing trainees. 


\section{REFERENCES}

1. Luttmann A, Jäger M, Griefahn B, Caffier G, Liebers F, Steinberg U. Preventing musculoskeletal disorders in the workplace. Geneva: WHO; 2003.

2. Waters TR, Dick RB, Davis-Barkley J, Krieg EF. A crosssectional study of risk factors for musculoskeletal symptoms in the work place using adapt from the General Social Survey (GSS). J Occup Environon Med. 2007;49(2):172-84, http://dx.doi.org/10.1097/JOM.0b013e3180322559.

3. Glover W, McGregor A, Sullivan C, Hague J. Work-related musculoskeletal disorders affecting members of the Chartered Society of Physiotherapy. Physiotherapy. 2005;91(3): 138-47, http://dx.doi.org/10.1016/j.physio.2005.06.001.

4. Neuman WP, Winkel J. Workshop: Making ergonomic intervention research effective. Proceedings of Premus 2004 The Fifth International Scientific Conference on Prevention of Workrelated Musculoskeletal Disorders; 2004 July 11-15, ETH Zürich, Switzerland. Gothenburg: Gothenburg University; 2004. p. 629-30.

5. Omokhodion FO, Balogun MO, Ola-Olorun FM. Reported occupational hazards and illness among hairdressers in Ibadan, Southwest Nigeria. West Afr J Med. 2009;28(1):20-3, http://dx.doi.org/10.4314/wajm.v28i1.48419.

6. Mussi G, Gouveia N. Prevalence of work-related musculoskeletal disorders in Brazilian hairdressers. Occup Med. 2008;58(5):367-9, http://dx.doi.org/10.1093/occmed/ kqn047.

7. Fang HL, Chen RCC, Fang HP, Xu Q. An ergonomic approach to an investigation into the risk factors leading to work related musculoskeletal disorder for Taiwanese hairdressers. International Association of Societies of Design Research. 2007 [cited 2014 Mar 30];49:89. Available from: http://www. sd.polyu.edu.hk/iasdr/proceeding/papers/AN\%20ERGO NOMIC\%20APPROACH\%20TO\%20AN\%20INVESTIGA TION\%20INTO\%20THE\%20RISK\%20FACTORS.pdf.

8. Kuorinka I, Jonsson B, Kilbom A, Vinterberg H, BieringSørensen F, Andersson G, et al. Standardised Nordic questionnaires for the analysis of musculoskeletal symptoms.
Appl Ergon. 1987;18(3):233-7, http://dx.doi.org/10.1016/00 03-6870(87)90010-X.

9. US Bureau of Labor Statistics. 2003 Survey of Occupational injuries and illnesses, 2003 [cited 2014 Mar 30]. Available from: http://www.bls.gov/iif.

10. Stefanakis M, Lou J, Pollintine P, Dolan P, Adams MA. ISSLS prize winner: Mechanical influences in progressive intervertebral disc degeneration. Spine. 2014;39(17): 1365-72, http://dx.doi.org/10.1097/BRS.0000000000000389.

11. Okojie OH, Isah EC. Assessment of occupational hazards among hairdressers in Benin City. Niger J Clin Pract. 2001;4(1):25-7.

12. Guo H-R. Working hours spent on repeated activities and prevalence of back pain. Occup Environ Med. 2002;59(10):680-8, http://dx.doi.org/10.1136/oem.59. 10.680 .

13. Wu CY, Yao CC, Lu CW, Chang KF, Chang CH. Evaluating the musculoskeletal disorders in the employee working in the beauty salon. Proceeding of the Health and Safety Conference. Taiwan; 2004.

14. Chuang W. A research on the musculoskeletal disorders of hairdressers in beauty salons. J Cheng-Shiu Univ. 2005;18:65-70.

15. English CJ, Maclaren WM, Court-Brown C, Hughes SP, Porter RW, Wallace WA, et al. Relations between upper limb soft tissue disorders and repetitive movement at work. Am J Ind Med. 1995;27(1):75-90, http://dx.doi.org/10.1002/ ajim.4700270108.

16. Lin M. Compensation of labour insurance cases among occupations in Taiwan. J Natl Inst Occup Saf Health. 2003;62.

17. Porter JM, Gyi DE. The prevalence of musculoskeletal troubles among car drivers. Occup Med. 2002;52(1):4-12, http://dx.doi.org/10.1093/occmed/52.1.4.

18. Lis AM, Black KM, Korn H, Nordin M. Association between sitting and occupational LBP. Eur Spine J. 2007; 16(2):283-98, http://dx.doi.org/10.1007/s00586-006-0143-7.

19. Leino T, Kähkönen E, Saarinen L, Henriks-Eckerman ML, Paakkulainen $\mathrm{H}$. Working conditions and health in 
hairdressing salons. Appl Occup Environ Hyg. 1999; 14(1):26-33, http://dx.doi.org/10.1080/104732299303386.

20. Guo H-R, Tanaka S, Cameron LL, Seligman PJ, Behrens VJ, Ger J, et al. Back pain among workers in the United States: National estimates and workers at high risk. Am J Ind Med. 1995;28(5):591-602, http://dx.doi.org/10.1002/ajim. 4700280504 .
21. European Agency for Safety and Health at Work. Workrelated musculoskeletal disorders: Prevention report. Luxembourg: European Agency for Safety and Health at Work; 2008.

22. Crippa M, Torri D, Fogliata L, Belleri L, Alessio L. [Implementation of a health education programme in a sample of hairdressing trainees]. Med Lav. 2007;98(1):48-54. Italian.

This work is available in Open Access model and licensed under a Creative Commons Attribution-NonCommercial 3.0 Poland License - http://creativecommons.org/ licenses/by-nc/3.0/pl/deed.en. 